\title{
LETTER OF EDITOR
}

\section{Dear Colleagues!}

\section{Dear Authors!}

\section{Friends!}

In the Universe, time is tirelessly moving into the Future. Each new unit of time is a witness of the birth of new ideas, current events, modern lives. Our consciousness determines their significance.

Today's vitality of the Planet Earth is determined by our friendship, tolerance, compassion, positive emotions, and enjoyment of each other's successes.

Our personal space (each of us!) includes natural resources, information networking, individuals' consciousness, perception of the world, different points of view, correct and incorrect decisions, and actions. We all challenge kindness in Eternity, regardless of everyone's beliefs and religions. We are looking for the aspiration and holidays of a SOUL.

We all coming to the Great Holliday Season. And the whole world is waiting for the Miracle of Hope to come on a New Year. We wish you and your family a Happy Holidays! We hope that your New Year will be filled with Peace, new ideas, and success!

These days, the Editors of the "Journal of Internal Medicine Science and Art," a new journal born in the tough 2020, are fully confident in this journal project's viability and success, its effectiveness in the professional informational space of medical professionals, and experts.

We are opened to new scientific and clinical research discussions and ideas. We, under no circumstances, will put up with informational deprivation. We are pleased with your desire to share research findings, new ideas, discuss results and cases with the international medical community to benefit our patients.

We welcome international cooperation in the critical fields of Global Human Health using our journal's pages. We are open to effective partnerships with authors, experts, reviewers, and medical practitioners to advance medical knowledge.

We appreciate everyone who contributed to our success this year. It has been an honor and a pleasure working with you! We are thankful for your professionalism, science, and educational support; that was a real pleasure working with you. Thank you for the opportunity to serve you!

As the year ends, we think our relationship will continue in 2021: we are looking forward to contributing to the future medical field's success.

Our sincerest warm greetings, and all good wishes to you; let your days be filled with happiness, success, and prosperity in the coming NEW Year!

\section{"Every end is a new beginning."}

